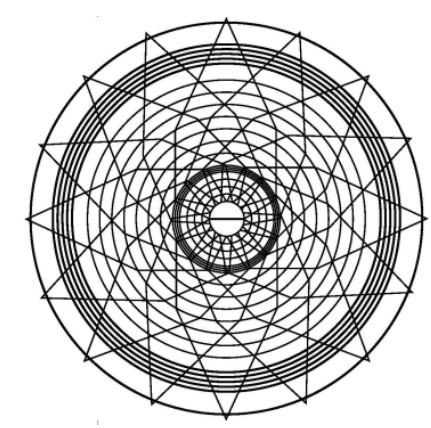

\title{
THE DEVELOPMENT OF THE RIGHT OF ACCESS TO OFFICIAL INFORMATION IN LATIN AMERICA ACCORDING TO THE CASE LAW OF THE INTER-AMERICAN COURT OF HUMAN RIGHTS
}

\author{
Perlingeiro R. \\ Full Professor of the Faculty of Law of Fluminense Federal \\ University (Niterói, Rio de Janeiro). Federal Appellate Judge of \\ the Federal Regional Court of the 2nd Region (Rio de Janeiro). \\ ricardoperlingeiro@id.uff.br
}

\begin{abstract}
:
This text is a descriptive analysis of the declaration of principles of the information access rights formulated by the Inter-American Juridical Committee of the Organization of American States, based on the case law of the Inter-American Human Rights Court, which were consolidated into the Model Inter-American Law on Access to Public Information, namely: the concept of the right to information; the scope of the right to information; proactive disclosure, administrative request; limits on information access; demonstrating fulfillment of the prerequisites for denying information access; administrative proceedings; penalties under administrative and criminal law; promoting and implementing the right to information.
\end{abstract}

Keywords: access to information, Human Rights, Latin America

\section{Introduction}

The Inter-American Human Rights Court, ${ }^{1}$ in its judgment on the case Claude Reyes et al. $v$. Chile of 2006, acknowledged the existence of a right to access official information- i.e., to request and obtain State-held information - under Article 13 of the American Convention of

\footnotetext{
${ }^{1}$ The Inter-American Court of Human Rights is an autonomous judicial institution based in the city of San José, Costa Rica. Together with the Inter-American Commission on Human Rights, it makes up the human rights protection system of the Organization of American States (OAS), which serves to uphold and promote basic rights and freedoms in the Americas. The Organization of American States established the Court in 1979 to enforce and interpret the provisions of the American Convention on Human Rights. Its two main functions are thus adjudicatory and advisory. Under the former, it hears and rules on the specific cases of human rights violations referred to it. Under the latter, it issues opinions on matters of legal interpretation brought to its attention by other OAS bodies or member states. The adjudicatory function requires the Court to rule on cases brought before it in which a state party to the Convention, and thus has accepted its jurisdiction, is accused of a human rights violation. In addition to ratifying the Convention, a state party must voluntarily submit to the Court's jurisdiction for it to be competent to hear a case involving that state. Acceptance of contentious jurisdiction can be given on a blanket basis - to date, Argentina, Bolivia, Brazil, Chile, Colombia, Costa Rica, Dominican Republic, Ecuador, El Salvador, Guatemala, Haiti, Honduras, Mexico, Nicaragua, Panama, Paraguay, Peru, Suriname, Uruguay, and Venezuela have done so[1] - or, alternatively, a state can agree to abide by the Court's jurisdiction in a specific, individual case.
} 


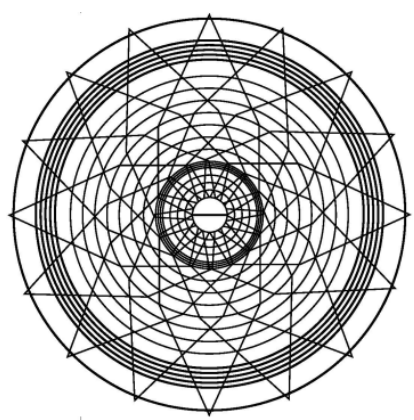

Перлинжейру P.

Развитие права доступа к официальной информации в Латинской Америке в соответствии с прецедентным правом Межамериканского суда по правам человека

Human Rights, which regulates the freedom of thought and expression. ${ }^{2}$ With that judgement, the I/A Court H.R. became the first international court to recognize that the right to access official information is a fundamental human right. $^{3}$

Subsequently, a considerable step forward was made in $2008,{ }^{4}$ with the approval of the principles of right of information access by the Inter-American Juridical Committee (IAJC) of the Organization of American States (OAS). ${ }^{5}$

In 2010, the Model Inter-American Law on Access to Public Information, ${ }^{6}$ approved by the OAS General Assembly, ${ }^{7}$ adopted the guidelines laid down by the Inter-American Human Rights Court's precedent as well as the information access principles proposed by the Inter-American Juridical Committee.

I will now present certain principles declared by the Inter-American Committee, which are situated midway between the Inter-American Court's case law and the OAS Model InterAmerican Law, with the aim of clarifying the Latin American trends in the right of access to official information.

\section{Concept of the right to information}

According to the OAS Inter-American Juridical Committee, "information access is a fundamental human right- with double connotations (individual and social) - which establishes that any person may access the information in possession of public bodies subject only to a limited set of exceptions that are compatible with a democratic society and proportionate to the interest that justifies them." 8

The universality of the right to information is enshrined in the Model Inter-American Law on Access to Information, which provides for the possibility of making information requests

\footnotetext{
2 Inter-American Court of Human Rights, Case of Claude-Reyes et al. v. Chile (judgment of 19 September 2006).

${ }^{3}$ Inter-American Commission on Human Rights 2015, p. 22.

${ }^{4}$ Inter-American Juridical Committee 2008, Principles on the right of access to infromation. See also Mendel 2009. p. 13.

${ }^{5}$ The Inter-American Juridical Committee (IAJC), headquartered in Rio de Janeiro, is one of the organs through which the Organization of American States (OAS) accomplishes its purposes. The Committee serves the Organization as an advisory body on juridical matters of an international nature and promotes the progressive development and the codification of international law.

${ }^{6}$ American Law on Access to Information to provide States with the legal foundation necessary to guarantee the right to access to information, as well as an Implementation Guide for the Model Law to provide the roadmap necessary to ensure the Law functions in practice. The final versions of both instruments were approved in March 2010 and presented the Permanent Council's Committee on Juridical and Political Affairs in April 2010. The Permanent Council, in May 2010, elevated a resolution and text of the Model Law to the fortieth regular session of the General Assembly, held in June 2010, which adopted resolution AG/RES 2607 (XL-O/10) on the Model Law - the complete text of which is attached to the resolution - and instructs the General Secretariat, through the Department of International Law, to provide support to the member States that so request in the design, execution, and evaluation of their regulations and policies on access to public information by citizens. The Model Law builds off of previous efforts the OAS has taken to advance the right of access to information, including the Joint Document Recommendations on Access to Information [CP/CAJP-2599/08], which provides detailed information on the right to access to information, as well as policy and legislative recommendations, and the Report on the Questionnaire "Legislation on and Best Practices of Access to Public Information of the Commission on Juridical and Political Affairs" [CP/CAJP-2608/08], which contains answers by the States and civil society to the questionnaire as well as recommendations from civil society organizations. In addition, the Model InterAmerican Law and the Guide for its Implementation, incorporate the principles outlined by the Inter-American Court on Human Rights in Claude Reyes v. Chile, as well as the Principles on Access to Information adopted by the Inter-American Juridical Committee [CJI/RES. 147 (LXXIII-O/08)].

${ }^{7}$ Organization of American States 2010, Model Inter-American Law on Access to Information.

${ }^{8}$ Principles on the right of access to information, resolution item 1.
} 


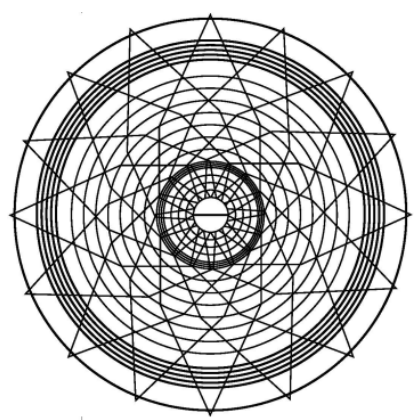

[Scientific Articles]

Perlingeiro R.

The development of the right of access to official information in Latin America according to the case law of the Inter-American Court of Human Rights

anonymously and without providing justifications for such requests, in keeping with the InterAmerican Court's understanding that "the supervision of the State by civil society, which is the aim of granting access to State-held information, and the nature of the information requested are sufficient motives for responding to the request for information, without requiring the applicant to prove a specific interest or a direct involvement". ${ }^{9}$

\section{Scope of the right to information}

The Inter-American Juridical Committee stated as follows: "The right of access to information applies to all public bodies, including the executive, legislative and judicial branches at all levels of government, constitutional and statutory bodies, bodies which are owned or controlled by government, and organizations which are owned or controlled by government, and organizations which operate with public funds or which perform public functions". ${ }^{10}$

\section{Proactive disclosure}

In the opinion of the Juridical Committee, "public bodies should disseminate information about their functions and activities - including their policies, opportunities for consultation, activities which affect members of the public, their budget and subsidies, benefits and contracts - on a routine and proactive basis, even in the absence of a specific request, so as to ensure that the information is accessible and understandable."11

Chapter II of the Model Inter-American Law, between Articles 9 and 14, gives a detailed account of the procedure and the information that is to be proactively disseminated by the authorities, including public policies and the warning that "no one shall be subject to any prejudice because of the application of a policy that has not been disclosed". ${ }^{2}$

\section{Administrative request}

The guiding principle is that "clear, fair, non-discriminatory and simple rules should be put in place regarding the processing of requests for information. These should include clear and reasonable timelines, provision for assistance to be given to those requesting information, access that is free of charge or for a fee that does not exceed the cost of copying and sending the information, and a requirement that where access is refused reasons, including specific grounds for the refusal, be provided in a timely fashion". ${ }^{13}$

\section{Limits on information access}

For the Juridical Committee, "Exceptions to the right to access should be established by statutory law and be clear and narrow" ${ }^{\prime 4}$, with the proviso that ordinary standards and rules, such as regulations, do not qualify as "law" for the purposes of that guideline. ${ }^{15}$ The InterAmerican Court explains the purpose of such statutory definitions as follows: "to guarantee

\footnotetext{
${ }^{9}$ Art. 5d, 5e Chapter I Model Inter-American Law on Access to Information.

${ }^{10}$ Principles on the right of access to information, resolution item 2.

${ }^{11}$ Principles on the right of access to information, resolution item 4.

${ }^{12}$ Art. 12, b and Art. 13.1, 2 Model Inter-American Law on Access to Information.

${ }_{13}^{13}$ Principles on the right of access to information, resolution item 5.

${ }^{14}$ Principles on the right of access to information, resolution item 6.

${ }^{15}$ A similar principle is found in German law: Grundsatz des Vorbehalts des Gesetzes. Inter-American Court of Human Rights, The Word "laws" of the American Convention on Human Rights. Advisory Opinion OC-6/86 of May 9, 1986, para 26-29.
} 


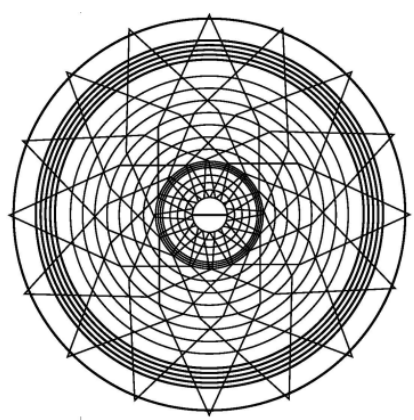

that restrictions on the right to information are not imposed arbitrarily by the public authorities, any such restrictions must be defined in advance by statutory law. ${ }^{16}$

Moreover, it should be pointed out that in Colombia, its constitutional court ruled that "generic or vague norms that could end up becoming a sort of general authorization for the authorities to keep any information whatsoever secret at their freely exercised discretion are unconstitutional". ${ }^{17}$

The Model Inter-American Law established 4 parameters for establishing limits on information access: a) application of the principle of proportionality, i.e., no more of the information should be kept secret than is strictly necessary to protect the State's legitimate interest in secrecy; ${ }^{18}$ b) whenever possible, disclosure should be partial, concealing only such information as deserves secrecy; ${ }^{19}$ c) no exception based on a violation of public interest may be invoked for any record that is more than 12 years old, and any extension of that period must be approved by the Information Commission and is limited to a further period of 12 years; ${ }^{20}$ d) no exception based on violation of public or private interests may be invoked in cases of serious human rights violations or crimes against humanity. ${ }^{21}$

\section{Demonstration of fulfillment of the prerequisites for exceptions to information access}

According to the Inter-American Court, the burden of proof lies with the public authority to rebut the presumption of its duty of disclosure by demonstrating and proving that the factual and legal prerequisites for the exceptions are fulfilled. ${ }^{22}$

In the Case of Gomes Lund et al. (Guerrilha do Araguaia) v. Brazil, the Inter-American Court decided that the State: "[...] must provide justifications for its refusal to supply information by demonstrating that it took all measures available to it in order to prove that there is no way to supply the requested information [...]". ${ }^{23}$

\section{8 (Non-judicial and judicial) procedure}

According to the Juridical Committee, "every individual should be afforded the right to bring an appeal against any refusal or obstruction to provide access to information before an administrative body, and to bring an appeal against the decisions of such administrative body before the courts." 24

The Model Law provides individuals with three different means to protect their right to information: a) internal appeal or request for reconsideration addressed to the authority that denied the right to information, as an optional preliminary measure before the other mechanisms of challenging the decision; b) external appeal addressed to a body distinct from

\footnotetext{
${ }^{16}$ Inter-American Court of Human Rights, Case of Claude-Reyes et al. v. Chile (judgment of 19 September 2006$)$ para 89.

${ }^{17}$ Constitutional Court of the Republic of Colombia, Sentencia C-491/07, Expediente D- 6583 (judgment of 27 June 2007), Legal Basis 11.

${ }^{18}$ Art. 44 Model Inter-American Law on Access to Information.

${ }^{19}$ Art. 42 Model Inter-American Law on Access to Information.

${ }^{20}$ Art. 43 Model Inter-American Law on Access to Information.

${ }^{21}$ Art. 45 Model Inter-American Law on Access to Information.

${ }^{22}$ Inter-American Court of Human Rights, Case of Claude-Reyes et al. v. Chile (judgment of 19 September 2006) para 93, 159

${ }^{23}$ Inter-American Court of Human Rights, Case of Gomes Lund et al. (Guerrilha do Araguaia) v. Brazil. (judgment of 24 November 2010) para 211.

${ }^{24}$ Principles on the right of access to information, resolution item 8.
} 


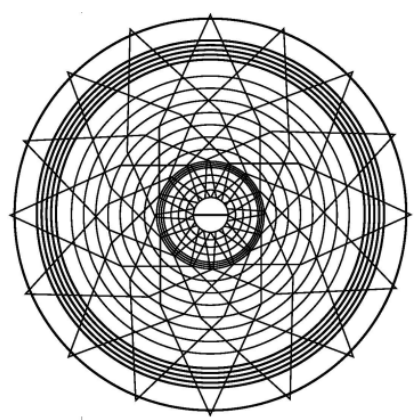

[Scientific Articles]

Perlingeiro R.

The development of the right of access to official information in Latin America according to the case law of the Inter-American Court of Human Rights

the body that denied the right to information, as an obligatory preliminary measure before court review; c) court review. ${ }^{25}$

In addition, another institution of fundamental importance established by the Model Law adopted only by a minority of [Latin American] countries - was the "Information Commission" as an independent and autonomous non-judicial body, intended to increase the effectiveness of access to official, normative and executive information, including the (non-judicial) disputeresolution function to rule on appeals of decisions denying access to information. ${ }^{26}$

We have, in fact, recently witnessed a trend, although still in its infancy, to create independent bodies for information access. In Latin America, however, there are only four examples of supervisory boards that tend to favor the effective independence guaranteed by prerogatives established by law: Consejo de Transparencia [Council of Transparency] ${ }^{27}$, in Chile; Instituto de Acceso à Información Pública [Institution of Public Information Access] ${ }^{28}$, in El Salvador; Instituto de Comisários [Institution of Commissioners] ${ }^{29}$ in Honduras; and the Organismos Garantes $^{30}$ [oversight agencies] in Mexico.

Thus, the new tendency to create supervisory bodies for information access endowed with prerogatives to act independently has met with only a faint-hearted echo in Latin America. This is so because the Continental European legal culture that has taken root in Latin American administrative law is incompatible with the system of quasi-judicial administrative bodies or administrative tribunals typical of common law countries. ${ }^{31}$

\section{Administrative and criminal penalties}

The Model Inter-American Law on Access to Information enshrines the principle that "sanctions shall be imposed on any individual who willfully denies or obstructs access to information in breach of the rules guaranteeing that right" ${ }^{32}$, adding that "it is a criminal offense to willfully destroy or alter records after they have been the subject of a request for information". ${ }^{33}$

\section{Promotion and implementation of the right to information}

States have a duty to promote a culture of information access; to take measures to ensure proper implementation of information access, and to adapt their laws as necessary to protect the right to information. ${ }^{34}$

Moreover, according to the Inter-American Court, the lack of preparation on the part of the public authorities to deal with the subject, especially by incorporating the criteria

\footnotetext{
${ }^{25}$ Art. 46-52 Model Inter-American Law on Access to Information.

${ }^{26}$ Art. 54-63 Model Inter-American Law on Access to Information. See Mendel 2007, p. 9. See also Snell 2007, p. 29.

${ }^{27}$ Art. 31-44 Chilean Law n 20.285 of July 11, 2008 on Access to Information (Ley sobre acceso a la información pública).

${ }^{28}$ Art. 51-60 Salvadoran Decree $n^{\circ} 534$ of March 3, 2011 on Access to Information (Ley de Acceso a la Información Pública).

${ }^{29}$ Art. 8-11 Honduran Legislative Decree no 170 of December 30, 2006 on Access to Information (Ley de Transparencia y Acceso a la Información Pública).

${ }^{30}$ Art. 8.III e IV, 30, 37-42 Mexican Law of May 4, 2015 on Access to Information (Ley General de Transparencia y Acceso a la Información Pública).

${ }^{31}$ See in general Perlingeiro 2016.

${ }^{32}$ Principles on the right of access to information, resolution item 9.

${ }^{33}$ Art. 64-66 Model Inter-American Law on Access to Information.

${ }^{34}$ Principles on the right of access to information, resolution item 10.
} 


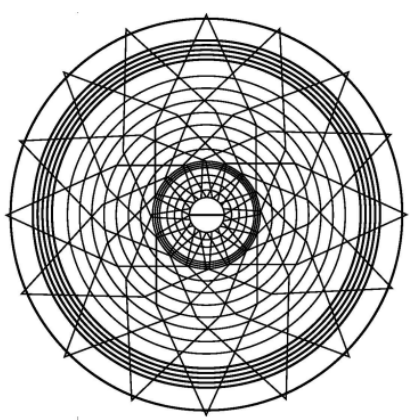

recommended by the OAS convention for the system of exceptions, indicates that the authorities are neglecting their duties to protect the right to information access; the States are therefore required to provide their bodies, public bodies, agents and authorities with proper legal training in a timely manner. ${ }^{35}$

\section{Closing considerations}

In general, the legislation and case law of Latin American countries - at least the former Iberian colonies that are signatories to the American Convention of Human Rights - comply with the Declaration of Principles of the Inter-American Juridical Committee of the Organization of American States (OAS) and the Model Inter-American Law on Access to Information, which systematize and codify the case law of the Inter-American Human Rights Court.

The recognition of the right to information as a fundamental right, as conceived of by the InterAmerican Juridical Committee, in keeping with the case law of the Inter-American Court, is well-established in the Latin-American legal systems and is an essential key factor in ensuring that legislators, authorities and judges implement the other principles recommended by the OAS.

Nevertheless, it was worth pointing out two procedural issues related to the right to information that would be easier to resolve in the political than in the legal sphere.

The first issue, which jeopardizes the principle of proper implementation of information access, is raised by the vague concepts concerning the exceptions to the right to information access, which are open to interpretation at the discretion of civil servants who lack legal training and offer no assurance of impartial action. Given the supremacy of fundamental rights, civil servants need to comply with constitutional principles governing information access even in cases where they lack sufficient statutory provisions to guide them. Since they often have no legal training, however, they have neither the cognitive abilities nor the credibility to handle such cases properly.

The second issue is raised by the principle of protection of the right to information, with respect to the prerogatives of independence of the administrative bodies responsible for processing appeals against decisions denying access to information. The proposal of the Model Inter-American Law, which has been accepted by only four Latin-American countries (Chile, El Salvador, Honduras and México), contains traces of quasi-judicial authorities and closed judicial review typical of administrative law in common law countries, which complicates matters in Latin America, which has a civil-law tradition.

This means that in order for information access to promote democratic supervision of the public authorities effectively - which is of incalculable importance in the current political and economic context of the Latin American countries- the compatibility between national law and the OAS principles must not be limited to declarations of rights and duties of information access; rather, a re-examination of the institutional guarantees of the right to information is also of paramount importance.

\footnotetext{
${ }^{35}$ Inter-American Court of Human Rights, Case of Claude-Reyes et al. v. Chile (judgment of 19 September 2006) para 164 e 165 .
} 


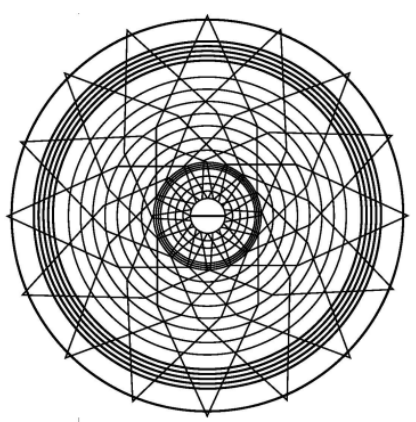

\section{[Scientific Articles]}

Perlingeiro R.

The development of the right of access to official information in Latin America according to the case law of the Inter-American Court of Human Rights

\section{REFERENCES:}

Asimow, M. (2015). Five Models of Administrative Adjudication. Forthcoming American Journal of Comparative Law, 63, 3-31. http://bit.ly/1yp8y4i. Accessed 13 February 2016.

Constitutional Court of the Republic of Colombia (Corte Constitucional de la República de Colombia), Sentencia C-491/07, Expediente D- 6583 (judgment of 27 June 2007). http://bit.ly/1Kh5Uht. Accessed: 13 February 2016.

Inter-American Court of Human Rights (1986). The Word "Iaws" of the American Convention on Human Rights. Advisory Opinion OC-6/86 of May 9, 1986. http://bit.ly/1WLG8QM.

Accessed 14 February 2016.

Inter-American Court of Human Rights, Case of Claude-Reyes et al. v. Chile (judgment of 19 September 2006). http://bit.ly/1EJmcBE. Accessed 2 January 2016.

Inter-American Court of Human Rights, Case of Gomes Lund et al. (Guerrilha do Araguaia) v. Brazil (judgment of 24 November 2010). http://bit.ly/1KdWmN3. Accessed 14 May 2016.

Inter-American Juridical Committee (2008). Principles on the right of access to information. CJI/RES. 147 (LXXIII-O/08). http://bit.ly/1nSf3fu. Accessed 4 May 2016.

Mendel, T. (2007). Acess to Information: The Existing State of Affairs Around the World. In Villanueva, E. (Ed.), Derecho de la información (pp. 3-12). Mexico: UNAM.

Mendel, T. (2009). El derecho a la Información en América Latina - Comparación Jurídica. Ecuador: UNESCO. http://bit.ly/1MVf6BA. Accessed 2 January 2016.

Organization of American States (2010). Model Inter-American Law on Access to Public Information. AG/RES. 2607 (XL-O/10). http://bit.ly/1nrf2hU. Accessed 2 January 2016.

Perlingeiro, R. (2016). A Historical Perspective on Administrative Jurisdiction in Latin America: Continental European Tradition vs. US Influence. British Journal of American Legal Studies, 5(1). http://ssrn.com/abstract=2592418. Accessed 6 May 2016.

Snell, R. (2007). Using comparative studies to improve freedom of information analysis. Insights from Australia, Canada and New Zealad. In E. Villanueva (Ed.) Derecho de la información (pp. 13-52). Mexico: UNAM. http://bit.ly/1YJAA6o. Accessed 10 May 2016. 


\section{РАЗВИТИЕ ПРАВА ДОСТУПА К ОФИЦИАЛЬНОЙ ИНФОРМАЦИИ В ЛАТИНСКОЙ АМЕРИКЕ В СООТВЕТСТВИИ С ПРЕЦЕДЕНТНЫМ ПРАВОМ МЕЖАМЕРИКАНСКОГО СУДА ПО ПРАВАМ ЧЕЛОВЕКА}

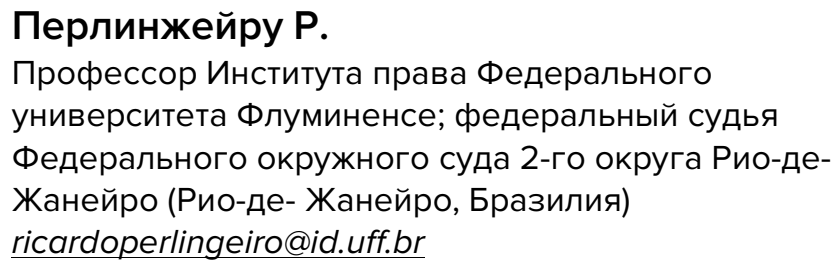

Аннотация:

Данный текст представляет собой дескриптивный анализ декларации принципов доступа к информации, сформулированной Межамериканским судебным комитетом Организации американских государств на основе прецедентного права Межамериканского суда по правам человека, консолидированного в Модельный межамериканский закон о доступе к публичной информации, включая следующие принципы: концепция права на информацию; объем права на информацию; проактивное раскрытие информации, административный запрос информации; ограничения доступа к информации; демонстрация выполнения необходимых условий для

отказа в доступе к информации; административный процесс; административные и уголовные наказания; содействие реализации и реализация права на информацию.

Полный русский перевод статьи будет опубликован в N² журнала «Коммуникации. Медиа. Дизайн» за 2016 год.

Ключевые слова: доступ к информации, права человека, Латинская Америка 


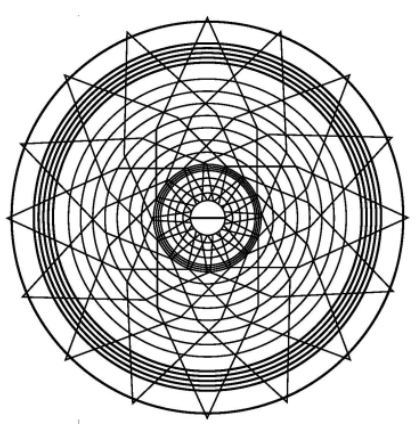

\section{[Scientific Articles]}

Perlingeiro R.

The development of the right of access to official information in Latin America according to the case law of the Inter-American Court of Human Rights

\section{БИБЛИОГРАФИЯ:}

Asimow, M. (2015). Five Models of Administrative Adjudication. Forthcoming American Journal of Comparative Law, 63, 3-31. http://bit.ly/1yp8y4i. Accessed 13 February 2016.

Constitutional Court of the Republic of Colombia (Corte Constitucional de la República de Colombia), Sentencia C-491/07, Expediente D- 6583 (judgment of 27 June 2007). http://bit.ly/1Kh5Uht. Accessed: 13 February 2016.

Inter-American Court of Human Rights (1986). The Word "Iaws" of the American Convention on Human Rights. Advisory Opinion OC-6/86 of May 9, 1986. http://bit.ly/1WLG8QM. Accessed 14 February 2016.

Inter-American Court of Human Rights, Case of Claude-Reyes et al. v. Chile (judgment of 19 September 2006). http://bit.ly/1EJmcBE. Accessed 2 January 2016.

Inter-American Court of Human Rights, Case of Gomes Lund et al. (Guerrilha do Araguaia) v. Brazil (judgment of 24 November 2010). http://bit.ly/1KdWmN3. Accessed 14 May 2016. Inter-American Juridical Committee (2008). Principles on the right of access to information. CJI/RES. 147 (LXXIII-O/08). http://bit.ly/1nSf3fu. Accessed 4 May 2016.

Mendel, T. (2007). Acess to Information: The Existing State of Affairs Around the World. In Villanueva, E. (Ed.), Derecho de la información (pp. 3-12). Mexico: UNAM.

Mendel, T. (2009). El derecho a la Información en América Latina - Comparación Jurídica. Ecuador: UNESCO. http://bit.ly/1MVf6BA. Accessed 2 January 2016.

Organization of American States (2010). Model Inter-American Law on Access to Public Information. AG/RES. 2607 (XL-O/10). http://bit.ly/1nrf2hU. Accessed 2 January 2016.

Perlingeiro, R. (2016). A Historical Perspective on Administrative Jurisdiction in Latin America: Continental European Tradition vs. US Influence. British Journal of American Legal Studies, 5(1). http://ssrn.com/abstract=2592418. Accessed 6 May 2016.

Snell, R. (2007). Using comparative studies to improve freedom of information analysis. Insights from Australia, Canada and New Zealad. In E. Villanueva (Ed.) Derecho de la información (pp. 13-52). Mexico: UNAM. http://bit.ly/1YJAA6o. Accessed 10 May 2016. 